\title{
Impartiality and Bias at the International Court of Justice
}

\author{
Gleider I. Hernández
}

\section{Keywords}

Impartiality, bias, judicial function, judges, independence, ICJ

\section{Constraints on the judicial role}

"On the consciences of the judges depends the justice of the Court's decisions." ${ }^{1}$

In an effort to explain impartiality and bias within the Court, studies using a variety of different approaches from virtually every area of the social sciences-psychology, sociology, and political theory amongst them-have attempted to discern the extent of the judges' bias ${ }^{2}$ All of these studies rest

DPhil (Wadham College, Oxford), LL.M (Leiden), LL.B \& BCL (McGill). Lecturer in Law, University of Durham. This piece is a redacted version of a chapter from the author's monograph, The International Court of Justice and the Judicial Function, (forthcoming, Oxford University Press, 2013). Disclaimer: from 2007 to 2010, the author served as Associate Legal Officer at the International Court of Justice, from 2007 to 2008 in the Legal Department of the Registry of the Court, and from 2008 to 2010, as law clerk in the chambers of Judges Bruno Simma and Peter Tomka. It goes without saying that the views presented in this article are wholly personal, and in no way whatsoever make use of any information learnt during the author's clerkship.

1 Speech made by President Guerrero at the Inaugural Sitting of the International Court of Justice (18 April 1946), (1946-47) ICJ Yearbook, at 38.

2 See for example T.O. Elias, 'Report: Does the International Court of Justice, as it is Presently Shaped, Correspond to the Requirements which Follow from its Functions as the Central Judicial Body of the International Community?', in H. Mosler and R. Bernhardt (eds), Judicial Settlement of International Disputes (Springer, 1974), at 19; E. Posner and M. de Figureido, 'Is the International Court of Justice Biased?', (2005) 34 JLS 599; E.B. Weiss, 'Judicial Independence and Impartiality: A Preliminary Inquiry', in L.F. Damrosch (ed), The International Court of Justice at a Crossroads (Transnational, 1987), at 123 [hereinafter 'Brown Weiss']; A. Rovine, 'The National Interest and the World Court', in L. Gross (ed), The Future of the International Court of Justice (Oceana, 1976), at 313 (although he was suggesting how the United States could leverage bias within the Court to further its national interest); G. Terry, 'Factional Behaviour on the International Court of Justice: An Analysis of the First and Second Courts 
on a basic premise, that bias and partiality are two characteristics anathema to the judicial robe. So goes this argument, the essence of the adjudicator's role, in addition to fulfilling the role of an impartial third party resolving disputes, is to avoid writing personal predilections, biases and prejudices into the law that they are entrusted to administer and safeguard or surrendering to considerations of personal or political expediency $\left.\right|^{3}$ This line of reasoning is surely sound: if the judicial role, whether domestic or international, involves in some measure to alleviate, mediate, resolve or otherwise decide disputes between parties, surely it is appropriate to demand some basic impartiality from judges in relation to the law, in that a judge can be entrusted to adjudicate conscientiously and in adherence with the nature of judicial work within a given legal order $4^{4}$

Scholarly treatment of the question of impartiality has raised another issue: that, because nationality or geography inevitably constitute overriding influences on international judges, bias is inevitable.$^{5}$ That claim remains prob-

(1945-1951) and the Sixth and Seventh Courts (1961-1967)', (1975) 10 Melbourne University Law Review 59; I. Ro Suh, 'Voting Behaviour of National Judges in International Courts', (1969) 63 AJIL 224 [hereinafter 'Suh']; T. Ginsburg, 'Bounded Discretion in International Judicial Lawmaking', (2005) 45 Va. J. Int'l L. 631 [hereinafter: 'Ginsburg']; J. Katz Cogan, 'Competition and Control in International Adjudication', (2008) 48 Va. J. Int'l L. 411; T. Hensley, 'National Bias and the International Court of Justice', (1966) 12 MJPS 568; W. Samore, 'National Origins v. Impartial Decisions: A Study of World Court Holdings', (1956) 34 Chicago-Kent LR 193 [hereinafter 'Samore']. Cf. A.M. Smith, 'Judicial Nationalism', (2005) 40 Tex. Int'l L.J 197 [hereinafter 'Smith'], who uses the same methodology and refutes any idea of national bias; and S. Schwebel, 'National Judges and Judges ad hoc of the International Court of Justice', (1999) 48 ICLQ 889 [hereinafter 'Schwebel'], at 893-4.

3 See W.O. Douglas, 'The Dissent: A Safeguard of Democracy', (1948) 32 Journal of the American Judicial Society 106; and R.A. Cass, 'Judging: Norms and Incentives of Retrospective Decision-Making', (1995) 75 Boston University Law Review 941, at 995 concluding that the principal incentive for judges is to adhere to professional norms "in order to maintain respect within the profession, to deflect criticism, and to conform to the judge's own expectations."

4 F. Mégret, 'International Judges and Experts? Impartiality and the Problem of Past Declarations', (2011) 10 LPICT 31, at 42-3. The Burgh House Principles on the Independence of the International Judiciary (published in 2004 by the Project on International Courts and Tribunals at University College London, and available at <http://www.ucl.ac.uk/laws/cict/docs/burgh_fin al_21204.pdf> [last accessed 30 August 2012]) attempt to entrench a notion of impartiality and independence for international judges more generally.

5 E.A. Posner and J.C. Yoo, 'Judicial Independence in International Tribunals', (2005) 93 Cal. L. Rev 1 , at 8 , suggest that decision-making in international courts would be more effective once the vested interests of the judges are acknowledged and accepted. But cf. M. Minow, 'Stripped Down Like a Runner or Enriched by Experience: Bias and Impartiality of Judges and Jurors', (1992) 33 William and Mary Law Review 1201, at 1207-8 who argues forcefully for the need to distinguish one's identity and perspectives, based on race, ethnicity, class or gender, from one's ability to judge impartially: "if being implicated means bias, then 
lematic, as it advocates a subjectivist analysis of judicial behaviour that is incomplete. By restricting partiality to the circular claim that "since [judicial decisions are] made by men who, in their attitudes, proclivities, and intellectual tendencies, are to a significant degree products of the environments that relate them to local and national systems of social values, there can be no men impartial in disputes between States" ${ }^{\prime 6}$ more important constraints are overlooked. Although factors such as national loyalty, the selection process, the manner in which judges align themselves into voting blocs on the bench and questions of procedural fairness 7 could surely prove important considerations if empirically cognisable, there is no evidence that the Court's judges systematically 'vote their preferences' or are instructed by their governments 8

Divining the reasons for judicial behaviour is a Sisyphean task riddled with methodological concerns. First, it is virtually impossible to ascertain the truth merely from interviews and constructed biographies without at least a degree of speculation, as judges are bound by the veil of secrecy that protects their deliberations; this might explain why a accurate scholarly treatment of judicial behaviour is probably unattainable 9 Moreover, theories of judicial behaviour based wholly on national bias remain incomplete, dismissing as they do other important influences which are objectively discernible: training in a particular legal tradition; professional training in diplomacy, government, or practice; institutional loyalty; and even an individual's judge's conception of the judicial

everyone is biased, and perhaps then no one can judge."

6 T. Franck, 'Some Psychological Factors in International Third Party Decision-Making', (1967) 19 Stan. L.R. 1217 [hereinafter 'Franck']. See also Terris et al, The International Judge: An Introduction to the Men and Women Who Decide the World's Cases (OUP, 2007), at 209 who concluded that "not even the strictest insistence on judicial impartiality can separate a judge entirely from his personal circumstances."

7 Brown Weiss, supra note 2, at 124.

8 See response to Posner in R. Higgins, 'Alternative Perspectives on the Independence of International Courts: remarks', 99 ASIL Proc. 135; R. Higgins, 'Reflections from the International Court' in M. Evans (ed), International Law (OUP, 2006) 3, at 3: "[c]ertainly the international judge is not 'responsible to' the particular States appearing before him/her. It is totally inappropriate for a State to assume, still less to say, that a particular Judge's vote in a case was due to his or her nationality (or race, or religion). Only those present in the Deliberation Chamber can know what views were held, by whom, and on what grounds. In fact, the dynamics of the legal exchanges between the Judges of the International Court in no way reflect tired stereotypes. Assumptions based on such ideas would be surprisingly wide of the mark.' See also A. Chayes, 'Nicaragua, The United States and the World Court', (1985) 85 Colum. L.Rev 1445, at 1447-8.

9 L.V. Prott, 'The role of the judge of the International Court of Justice' (1974) 10 RBDI 473 [hereinafter 'Prott'], at 473. 
function within the international legal order ${ }^{10}$

In this respect, criticism of judges often rests on the appraiser's valuesystem and his or her subjective understanding of the judicial function without appreciating the complex manner in which a judge's particular judicial methodology and discipline also operate in shaping judicial decisions ${ }^{11}$ This article aims therefore to move beyond such subjective analyses, and will eschew matters of corruptibility and of national or political bias. It will also ignore the nationality of the judges, the political interests of states, and questions relating to the representation of different regions or legal traditions on the bench, leaving these considerations to other authors ${ }^{12}$ As an analysis of constraints incumbent on international judges depends on far more than their personal history or psychological profile, and is in fact the fruit of the unique constraints inherent in the judicial role ${ }^{13}$ this piece will focus on distilling those "ordinarily unchallengeable factors"14 ${ }^{14}$ which do operate upon the Court through the "deliberately

10 O. Spiermann, International Legal Argument in the Permanent Court of International Justice (CUP, 2005) [hereinafter 'Spiermann'], at 27. These factors might be considered as part of the definition of a judge's 'legal culture'. See L. Friedman, 'The Concept of Legal Culture: A Reply' in D. Nelken (ed.), Comparing Legal Cultures (Aldershot, 1997) 33, at 34: "ideals, values, expectations and attitudes towards law and legal institutions, which some public or some parts of the public hold."

11 See R. Dworkin, ‘The Judge's New Role: Should Personal Conviction Count?’, (2003) 1 JICJ 4 [hereinafter 'Dworkin']. For a comparative view of how this occurs within municipal legal orders see Prott, supra note 9, at 474 arguing that judges internalise the expectations laid out by external agents as their own personal standards of behaviour; and Franck, supra note 6 , at 1217 claiming that there exist subconscious and concealed impulses which predetermine the result of the decision-making process of the international judge.

12 H. Lauterpacht, The Function of Law in the International Community (Clarendon Press, 1933) [hereinafter Lauterpacht, Function of Law], at 211-5 is similarly dismissive of these considerations, although see H. Lauterpacht, 'Observations concerning the Report of Judge Huber on Amendment of the Statute of the International Court of Justice', in H. Lauterpacht, International Law: being the Collected Papers of Hersch Lauterpacht, Vol 5: Disputes, War and Neutrality, Parts IX-XIV (CUP, 2004) 99 [hereinafter 'Lauterpacht, Amendments'], at 100-105. See also in the same volume H. Lauterpacht, 'Contents for the Revision of the Statute of the International Court of Justice', 114 [hereinafter 'Lauterpacht, Revision'], where he suggests various modifications to the selection process. For an interesting, albeit teleological approach to these phenomena, see M. Manouvel, Les opinions séparées à la Cour internationale: un instrument de contrôle du droit international prétorien par les États (l'Harmattan, 2005) [hereinafter 'Manouvel'], at 170-215. See also R. Mackenzie and P. Sands, 'International Courts and Tribunals and the Independence of the International Judge', (2002) 44 Harv. Int'l L.J 271, at 280-2 for suggestions on safeguarding the impartiality and independence of international judges.

13 R. Dworkin, Law's Empire (Belknap Press, 1986), at 17-8, 401.

14 K. Malleson, 'Safeguarding Judicial Impartiality', (2002) 22 Legal Studies 53, at 61 who lists, 
deliberative and reflective process ${ }^{15}$ of judicial decision. Those factors include the direct restrictions due to its institutional structure, concern for its prestige and authority, which may also include concerns of individual members for their legacy and reputation ${ }^{16}$ whether what Lauterpacht calls a "judicial idealism intent upon extending the domain of law' ${ }^{17}$ exists, and concerns about the appearance and form of impartiality. These influences are inherent in the adjudicative discipline ${ }^{18}$ and the reason for focussing on these particular constraints is that, unlike subjectivist concerns that cannot be empirically identified, there is sufficient evidence in the Court's institutional structure and procedure, as well as occasionally in its own judgments, where such constraints manifest themselves. As such, the preoccupation over impartiality within the Court remains live; and elucidating how the Court understands impartiality remains an important consideration in discerning how the Court understands its own judicial function.

inter alia, social and educational background, service or employment background or history, political associations, and membership in certain bodies as such "unchallengeable" factors.

15 E.W. Thomas, The Judicial Process: Realism, Pragmatism, Practical Reasoning and Principles (CUP, 2005) [hereinafter 'Thomas'], at 242.

16 A.-M. Slaughter and L. Helfer, 'Why States Create International Tribunals: A Response to Professors Posner and Woo', (2005) 93 California Law Review 3 [hereinafter 'Slaughter and Helfer'], at 6. Slaughter and Helfer have articulated a theory of "dependent adjudication" which posits that several factors, inherent in the international legal order, require a system in which independent tribunals are "unlikely to overstep their bounds and are far more likely to advance states" long-term interests, and therefore are institutions with "constrained independence", going so far as to call judges "fiduciaries' of States' interests". Ginsburg, supra note 2, calls this "bounded discretion." A not-dissimilar idea is advanced by K. Alter, 'Agents or Trustees? International Courts in their Political Context', (2008) 14 EJIR 33, at 39-41 and 44-7 who argues that judges are "trustees" rather than agents, distinguished from the latter by the relative independence and individual qualifications, but nevertheless acting "on behalf of" States appointing them. Cf. Posner and Yoo, supra note 5, at 27 who transcend arguments of partiality or bias simpliciter to claim that not only do international judges act as conscious agents of their national State's interests, but that their actual function of ICJ judges is to circumscribe and control the authority of the Court's judgments. Methodological difficulties permeate these claims of State dependence: "it is the essence of being a judge to be impartial and independent, and he or she publicly will not relinquish that role. To argue otherwise without concrete evidence is to theorise on the basis of speculation." Unusually, Cogan, supra note 2, at 415 argues that in fact, because States are unable to control judicial decision-making, "we need to think anew about how to maintain control over [international courts]."

17 Lauterpacht, Function of Law, supra note 12, at 205. Lauterpacht explains that this tendency "ceases to be legitimate when, in the pursuit of a progressive and ethical solution, judges are driven to disregard a clear rule grounded in the practice of States and in the imperative requirements of the stability of the law", at 209.

18 Ibid., at 243. 


\section{Defining impartiality}

Despite the frequency with which judges are exhorted to be impartial, little scholarship seems to have conceptualised the notion of impartiality, even at the domestic level ${ }^{19}$ It is true that impartiality is a difficult concept to articulate from a legal standpoint, raising as it does the basic question: impartiality in relation to what? Proximity to the question at hand has two facets: it may either contaminate one's ability to be impartial, or in fact reinforce one's ability to reason from expertise ${ }^{20}$ More importantly, one's theory of justice, on the conception of the 'common good', and on the nature of law all inevitably colour one's conception of impartiality. The classic jurisprudential debates between Herbert Hart and Lon Fuller also led to diverging views on the judicial function and the role impartiality could play within it. Hart's argument, in the main, was that that judicial impartiality could be realised by courts weighing and balancing the competing interests of claimants ${ }^{21}$ but only in the light of valid legal rules-rules accepted as valid because they pass Hart's rules of recognition-would form the reason for his/her judgment ${ }_{22}^{22}$ Fuller, by contrast, situated judicial impartiality differently: whilst certainly a judge was to remain neutral among the moral positions embedded in the substantive law or rule he/she meant to apply, the judicial function required fidelity to the law's internal morality in assessing the validity of such rules: ${ }^{23}$ impartiality thus took a substantive dimension. As such, whilst their substantive directives to judges to be impartial are much the same, the content of the term 'impartiality' is rather different.

The difficulties in defining the term with any certainty suggest that an

19 W. Lucy, 'The Possibility of Impartiality', (2005) 25(1) Oxford Journal of Legal Studies 3, at 4 suggests that the notion of impartiality figures very sparingly in Anglo-American jurisprudential work on adjudication, singling out especially Dworkin, supra note 13, at 234 and N. MacCormick, Legal Reasoning and Legal Theory (OUP, 1978), who does not consider the concept at any length.

20 M. Minow, 'Stripped Down Like a Runner or Enriched by Experience: Bias and Impartiality of Judges and Jurors', (1992) 33 William and Mary Law Review 1201, at 1204-5 points out that the impartiality of being unfamiliar with issues of major importance may guard against prejudice, but may lack the knowledge to distinguish between fact and the interpretation given by parties' counsel.

21 H.L.A. Hart, The Concept of Law (Clarendon Press, 1994), at 205.

22 Ibid., 104. Hart's claim on the judiciary's reasons to be an internal statement on the validity of law.

23 L.L. Fuller, The Morality of Law (Yale University Press, 1969), at 130-1. By internal morality, one would be advised to recall Fuller's eight desiderata for the effective existence of a legal system, rather than any substantive or primary rules of law. 
understanding of impartiality cannot be discerned through any overarching normative proposition, but is instead dependent on the context in which it is invoked ${ }^{24}$ For the Court, impartiality seems generally to be demanded in the sense of judicial independence 25 this translates into acting "independently of all outside influence or interventions whatsoever, in the exercise of the judicial function entrusted to it alone by the Charter and its Statute. ${ }^{26}$ Defined as such, it is essentially relational, and encompasses primarily procedural impartiality, in that both parties are treated equally, and the outcome is wholly dependent on the direct dispute ${ }^{27}$ If one focuses specifically on the International Court's practice, its relatively formalistic standards suggest a concern for adherence primarily, if not exclusively, using this definition ${ }^{28}$

A caveat: judicial decision-making at the Court cannot be fully understood purely by reference to formal attributes of the institution; although these may be crucial to understanding its judicial function, regard must be had for the functions attributed to the individual judges themselves. In this respect, a Member of the International Court exercises a function somewhat distinct from that of the Court itself. From an adjudicatory perspective, the judge is expected to uphold the function of the Court and the international legal norms that body is bound to apply. However, rooted in the consensual and arbitration-based history of international dispute settlement, there also exists discernible pressure on judges to fulfil a certain representational role ${ }^{29}$ Despite

24 Lucy, supra note 19 , at 5.

25 See for example T. Meron, 'Judicial Independence and Impartiality in International Criminal Tribunals', (2005) 99(2) AJIL 359, at 359-60.

${ }^{26}$ Legal Consequences for States of the Continued Presence of South Africa in Namibia (South West Africa) notwithstanding SC Res. 276, Advisory Opinion, ICJ Reports 1970, p. 16, at 23, para. 29. See also M.J. Aznar Gómez, 'Article 2', in Zimmermann et al (eds), The Statute of the International Court of Justice: A Commentary (OUP, 2006), 205, at 209 who emphasises that independence is to protect judges from any external pressures, so that they rely only on the facts and the law.

27 To ensure 'outcome impartiality' extrinsic factors, such as the needs and status of the parties in dispute, past and present deeds unrelated to the immediate dispute, and the impact of the outcome are to be ignored. See Lucy, supra note 19, at 8 and 17-21.

28 See for example Article 17(2) Statute of the International Court of Justice, as annexed to the Charter of the United Nations (26 June 1945) 1 UNTS xvi; UKTS 67 (1946), Cmd 7015 [hereinafter 'ICJ Statute'], where judges are called upon to recuse themselves from a particular case if they have previously taken part as "agent, counsel, or advocate of one of the parties, or as a member of a national or international court, or of a commission of enquiry, or in any other capacity" related to the case. As notes P. Couvreur, 'Article 17', in Zimmerman, supra note 26, 337, at 346 no member of the Court has ever been impugned with violating this provision.

29 See R. Mackenzie et al, Selecting International Judges: Selecting International Judges: Principle, 
the emphasis on judicial independence and high qualifications stipulated in Article 2 of the Statute ${ }^{30}$ Article 9 embodies the notion that "as a whole", the Court should ensure the representation of "the main forms of civilization and of the principal legal systems of the world.' 1 This representational element permeating the judicial role has raised, and continues to raise, concerns that the role of the Court's judges is constrained: already during the time of the PCIJ, Moore, Loder and Anzilotti cautioned that "of all the influences to which men are subject, none is more powerful, more pervasive, or more subtle, 32 than that of national bias; that preoccupation underlies the exhortation towards impartiality embodied in the judicial oath ${ }^{33}$ That distinction, between judge and judicial institution, permeates the discussion that follows below.

Process, and Politics (OUP, 2010), at 25 who argues that this is perhaps no different than in domestic courts, where there is increasing demand that the judiciary "needs to be broadly reflective of the make-up of society in order for it to command public confidence and maintain political legitimacy as an unelected institution of power". It should be noted that considerations of "representation" on the domestic plane turn primarily on ethnicity, gender and socio-economic status. See for example Lucy, supra note 19, at 15-6 referring to B. Wilson, 'Will Women Judges really make a Difference?', (1990) 28 Osgoode Hall Law Journal 507; and B. Hale, 'Equality and the Judiciary: Why Should We Want More Women Judges?', (2001) (Autumn) Public Law 489.

30 According to Article 2 of the ICJ Statute, supra note 28, the Court shall be composed of a body of "independent judges, elected regardless of their nationality from among persons of high moral character, who possess the qualifications required in their respective countries for appointment to the highest judicial offices, or are jurisconsults of recognized competence in international law."

31 Article 9 of the ICJ Statute, supra note 28, The exact terms in this provision came at the insistence of Adatci (Japan) in 1920: see PCIJ Advisory Committee of Jurists, Procès-verbaux of the Proceedings of the Committee, June 16th-July 24th 1920, with Annexes (Van Langenhuysen Bros, 1920) [hereinafter Procès-verbaux'], at 118, 136, 168; nationality was obviously an important silent consideration. G. Abi-Saab, 'Ensuring the Best Bench: Ways of Selecting Judges: Presentation by Professor Georges Abi-Saab', in C. Peck and L. Roy (eds), Increasing the Effectiveness of the International Court of Justice: Proceedings of the ICJ/UNITAR Colloquium to Celebrate the 50th Anniversary of the Court (Nijhoff, 1997), at 168 resolves the "whiff (soupcon) of contradiction" between the two provisions by emphasising that the representational qualities stipulated in Article 9 are in regard to the legal systems of the world rather than judges' national States.

32 Report of Judges Loder, Moore, and Anzilotti to the Permanent Court (2 September 1927), PCIJ Series E No 4 (1927-28), at 75.

33 Article 20 of the ICJ Statute, supra note 28, provides that "[e]very member of the Court shall, before taking up his duties, make a solemn declaration in open court that he will exercise his powers impartially and conscientiously." 


\section{Certain constraints on judicial behaviour}

\subsection{Legal education and training; views on the function of law}

Legal education and training constitute a constraint upon both domestic and international judges, who are institutionally "conditioned in such a way as to virtually preclude the possibility of stepping outside the bounds of legitimate judicial reasoning,"34 Judges also demonstrate loyalty to their oath of impartiality, characterised as "sacred" by Lauterpacht, who considered judicial impartiality a conscious decision to assume the moral duty of "the enlightened consideration of the paramount interest of peace and justice entrusted to the care of judges.' 35

As mentioned earlier, besides the obligation to remain impartial, Article 9 also suggests that within the Court, there should be representation of the "main forms of civilization and of the principal legal systems of the world.' 36 From the outset, these provisions aimed to reflect the "distinct forms of legal education" through which one could approach a unified public international law ${ }^{37}$ This seems borne out in practice: there appears to exist a remarkable intellectual homogeneity amongst the judges, one which transcends their varied origins ${ }^{38}$ Though this in no way implies universality of thought, the extent to which Western conceptions of public international law and the judicial function

34 Thomas, supra note 15, at 245.

35 Lauterpacht, Function of Law, supra note 12, at 215. Lauterpacht argued that although international judges can act impartially, institutional steps should be taken to ensure said impartiality, primarily through the proscription of any factors of national representation, especially taking issue with the institution of the judge ad hoc, which he criticised as possessing a "fatal lack of rationality", at 233-6. He also freely acknowledged that "by birth, training, and community of sentiment and interest", judges belonged to one particular section of a population, at 216-7.

36 Although, as S. Rosenne, The Law and Practice of the International Court 1920-1996, Vol. 1 (Nijhoff, 1997) [hereinafter 'Rosenne, Law and Practice'], at 367 concludes, the substance of Article 9 is hardly to impose an obligation on the electors, and there is no obligation on States.

37 B. Fassbender, 'Article 9', in Zimmermann, supra note 26, 261, at 267. In practice, "diversity" seems to be ensured through a convention whereby the Court's composition broadly resembles that of the Security Council, with a "tradition" that its permanent members also are continually represented on the bench.

38 An unpublished memorandum prepared by former Registrar Hambro for the ASIL Study Panel on the Future of the International Court of Justice was reprinted in E. Gordon, 'Observations on the independence and impartiality of the Members of the International Court of Justice', (1987) 2 Connecticut Journal of International Law 397 [hereinafter 'Gordon'], 
permeate their legal training is remarkable, to the point where distinction between Western and non-Western judges on the basis of their expressed legal reasoning is impossible ${ }^{39}$ The duopoly of English and French as the Court's sole working languages perhaps compounds the problem ${ }^{40}$ and might partly explain why all of the current judges-and the vast majority of its past judges-have read law in universities in the United States, the United Kingdom or France ${ }^{41}$ Doubtless there is great diversity in the perception of the judicial function within even those three traditions: the distinction between the civil law traditions and common law traditions embodied by these three jurisdictions could be argued to be broadly representative of a fair, if not universal, sampling of States ${ }^{42}$ Yet overall, if one moves away from pure geographical representation and considers other factors, the reputed

at 407. Hambro argued that "[Judges] are to apply international law, but even international law is taught differently and applied differently in different countries according to the legal systems prevailing ... Nobody can doubt that the judges in applying such principles are influenced by their backgrounds.... This explains sufficiently why the voting at times looks as if it goes according to nationality; but this does not in any way even remotely imply that the judges receive any kind of intimation, let alone instructions, from their governments on how they should vote."

39 L.V. Prott, 'The Style of Judgment in the International Court of Justice', (1970-1973) Aust. YBIL 82. See also R. Hoffman and T. Laubner, 'Article 57', in Zimmermann, supra note 26, at 1211 who claim that any distinctions between the judges having existed within the Court (i.e. developed/developing States) have become much less apparent since the early 1990s; and M. Shahabuddeen, Precedent in the World Court (Grotius Publications, 1997), at 204. The reverse was true regarding Soviet (although not Polish) judges during the Cold War. See for example Z.L. Zile, 'A Soviet Contribution to International Adjudication: Professor Krylov's Jurisprudential Legacy', (1964) 58 AJIL 359, at 381; and K. Grzybowski, 'Socialist Judges in the International Court of Justice', (1964) 3 Duke Law Journal 536.

40 For further consideration of the intricate relation between linguistic competence and legal concepts see G.I. Hernández, 'On Multilingualism in the International Legal Process', in H. Ruiz-Fabri et al (eds), Select Proceedings of the European Society of International Law, Volume 2 (Hart, 2010) 441. Mackenzie, supra note 29, at 82, note that the relatively confined choice of official languages in fact constrains the candidate pool in States where neither of these is spoken as an official language, thus further narrowing the possibilities only to those candidates who have had the opportunity to become competent in one of the two official languages.

${ }^{41}$ Of the present fifteen judges, six studied or researched postgraduate law in the United Kingdom (five at Cambridge), five in the United States (three at Harvard) and three in France (two at Paris). Judge Yusuf, the lone judge neither to have studied nor have taught in one of these three States, completed his doctorate at HEI-Geneva, an institution very closely connected to the French international legal tradition.

42 As Fassbender, supra note 37, at 275 summarises, in practice this means the influence of legal systems based on English common law and on Roman civil law, with Islamic law traditions are also generally represented. See also Mackenzie, supra note 29, at 41-3, who express 
diversity of the bench takes on a different cast: the homogeneity of their legal training arguably conditions their adherence to a specific vision of the judicial role, establishing common shared assumptions which serve to integrate their contribution in a manner that will persuade and appeal to, or at least not affront, their colleagues ${ }^{43}$

\subsection{Conceptions of institutional propriety and 'belonging'}

Judges have a keen sense of their own participation in upholding the function of the court of which they are a member; and they inevitably perceive themselves as "part of an institution and an ongoing legal process that began well before them and that will continue long after they have gone. ${ }^{44}$ This sense of continuity and institutional belonging is entrenched and formalised by the collective drafting process of the Court, creating a sense of collective loyalty where each judge will strive to meet the individual and collective expectations of their colleagues in respect of their expectations of the judicial role and that of a member of the institution ${ }^{45}$ In "complete equality" with their peers, ${ }^{46}$ judges ad hoc are held to the same standard, although the specific nature of that institution creates a somewhat different expectation of their role, which will not be explored here 47

Consistent with the sense of institutional propriety and belonging is the sense by judges of their own individual function. As Theodor Meron has suggested, any person accepting international judicial office must accept "the values, the duties, and the instincts of one who holds such an office. 48 There is doubtless heterogeneity in these self-perceptions, with divergence in judges'

concerns about the neglect of other systems at the expense of these systems; but $c f$. Rosenne, Law and Practice, supra note 36, at 397 decrying the heterogeneity of the Court as a possible cause of unpredictability in litigation.

43 E. McWhinney, The International Court of Justice and the Western Tradition in International Law (Nijhoff, 1987), at 151, applauds this homogenization as part of an "internationalising, universalising force" in international society.

44 Thomas, supra note 15, 246.

45 Ibid., at 247. See also Cass, supra note 3, at 970-2.

${ }^{46}$ Article 31 ICJ Statute, supra note 28.

47 See G.I. Hernández, The International Court of Justice and the Judicial Function (OUP, forthcoming 2013), Chapter V, where an expanded version of this present article will further explore the role of the judge ad hoc.

48 Meron, supra note 25, at 360. 
perceptions of the role of the Court in law-making, for example ${ }^{49}$ and with some judges arguably even defining their role in opposition to the institution of which they form a part ${ }^{50}$ Yet, for all this, some broad-brush, basic notions of a judge's role can be identified ${ }^{51}$ A judge is held to decide a case in line with a correct or 'proper' interpretation of the applicable law: in short, deciding similar cases consistently with other decisions and more general legal principles ${ }^{52}$ In line with this requirement, a judge is called upon to strive to decide in a principled, objective manner ${ }^{53}$ with the absence of prior emotional attachment to a given case, either by direct personal interest or through strong political or ideological views that would predetermine the outcome ${ }^{54}$ Frédéric Mégret calls this a dédoublement, the ability of the individual to reduce $\mathrm{him} /$ herself to the function of the judge, and to limit the subjectivity of the person ${ }^{55}$

An interesting area in which institutional propriety may have imposed itself is in relation to gender balance on the bench. Given the paucity of female representation on international benches generally, efforts have been made in other courts to ensure a more appropriate gender balance ${ }^{56}$ with the view

${ }^{49}$ Ginsburg, supra note 2, at 668 argues that many international judges will have internalised a limited conception of their law-creating role. See also Declaration, Separate Opinion (Judge Simma) in Case Concerning Oil Platforms (Islamic Republic of Iran v United States of America), Merits, Judgment, ICJ Reports 2003, p. 161, 324, at 325, inveighing against the "inappropriate self-restraint" of his colleagues in addressing the legal limits on the use of force. In his final Separate Opinion, this time in the Application of the Interim Accord of 13 September 1995 (Former Yugoslav Republic of Macedonia v Greece), Judgment of 5 December 2011, Judge Simma characterised the Court's abstinence in clarifying the legal status of the exception non adimpleti contractus rule a "transactional" approach (para. 6), and as a form of "haptophobia" (fear of being touched) (para. 7).

${ }^{50}$ It is true that the occasional 'great dissenter' appears within the Court, who consciously casts him or herself in the role of challenging the institution from within, and calling it to account for failing to conform with that judge's expectations of the judicial role. That role seems presently to be occupied by Judge Cançado Trindade, whose lengthy dissenting opinions regularly exceed the length of the Court's own judgments.

51 See for example B.N. Cardozo, The Nature of the Judicial Process (Yale University Press, 1921), at $12-3$.

52 Lucy, supra note 19, at 23, calls this principle of treating like cases alike a "bulwark against partiality", as it imposes a burden on a court to explain why a putatively similar case is not actually sufficiently legal similar to the current case, and that burden at least makes improper partiality more difficult than it might otherwise be.

53 Cass, supra note 3, at 947-8.

54 As Mégret, supra note 4, at 44 points out, obvious ethnic, racial or religious biases would figure amongst such predispositions.

55 Ibid.

56 See for example Article 36(8)(a)(iii) of the Rome Statute for the Establishment of an Interna- 
put forward that this would ensure that certain values are considered by the bench. In some respects, this might be true: certainly a feminist approach to law and legal reasoning might yield different judicial outcomes, inasmuch as the law sometimes contains aspects of context or situation which do not address the specific concerns of the feminist critique ${ }^{57}$ But that is altogether a different assertion than claiming that the mere presence of women necessarily modifies judicial reasoning. For example, it can safely be asserted that a consciously gendered approach to international law is wholly absent in the long line of case law in which the Court's first female judge, Dame Rosalyn Higgins, participated in or presided over ${ }^{58}$ Although generalisations based on Judge Higgins' tenure are incautious, given her singular role for many years ${ }^{59}$ the recent election of additional women judges-Xue Hanquin, Joan Donoghue

tional Criminal Court, 2187 UNTS 90, which requires that each gender be represented by no less than one third of the bench, or Article 12(2) of the Protocol on the African Court of Human and People's Rights, OAU Doc. OAU/LEG/EXP/AFCHPR/PROT (III) (9 June 1998), which contains a more general exhortation.

57 See for example the study by R. Hunter et al, The Feminist Judgments (Hart, 2010), where several well-known judgments in English law have been drafted from a consciously gendered perspective; and S. Sherry, 'The Gender of Judges', (1986) 4 Law and Inequality 159, who examines the different claim that women judges reason differently from men. But $c f$. the observation by H. Charlesworth and C. Chinkin, The Boundaries of International Law: A Feminist Analysis (Manchester University Press, 2000), at 81-2 concluding with rue, that the international legal training of women conditions them to think about law no differently from men; and that in any event, the practice of collective drafting is such that it would reduce the scope of alternative or controversial approaches in the majority opinions.

58 This is surely intentional. In the words of Judge Higgins herself: "Men sometimes speak about women having more intuition and so forth. I don't accept that. I think we're either smart lawyers or not smart lawyers; we either know a lot or we don't know a lot. Gender has nothing to do with it. In the international criminal field some of the women judges say it really does make a difference whether you're a woman judge when you're looking at issues of rape and so forth. I cannot stand in their shoes, and disagree with them. But at the same time I like to think that both sexes are equally appalled at such things. And coming back to the work of the International Court of Justice, I cannot believe that anything I've said about where I think a border runs, or a use of force has occurred, or a resource belongs to one State or the other, has anything to do with gender. Nothing!” The full transcript of the interview can be found at <http://www.peacepalacelibrary.nl/2011/12/interview-with-prof-rosalyn-higgins> [last accessed 30 August 2012].

59 In fact, as Malleson et al, supra note 14, at 163, have calculated, if expressed in female and male "court years", over the period of ICJ history until Judge Higgins' retirement in February 2009, there have been fifteen female years compared to nine-hundred and forty-five male years. Even when States have been given a choice to nominate a woman as judge ad hoc, they have only elected to do so twice: Suzanne Bastid was nominated by Tunisia in Application for Revision and Interpretation of the Judgment of 24 February 1982 in the Case Concerning the Continental Shelf (Tunisia v Libyan Arab Jamahiriya), Judgment, ICJ Reports 1985, p. 192, at 
and Julia Sebuntinde-may yield more possibilities for scholarly treatment of the question of gender balance and whether it may influence or modify judicial behaviour at the Court 60

\subsection{Wider external community expectations}

The Court's judges are obliged to pay heed to the expectations of States and the wider United Nations framework ${ }^{1}$ In the early days of the Court, thenPresident Basdevant admitted candidly that its docket would be dependent on governments, the political organs of the $\mathrm{UN}$, and the decisions that these might choose to bring before it ${ }^{62}$ Efforts were made from the outset to separate nominations from States, placing the process with the four members of the "national group' of the Permanent Court of Arbitration, which nominates a candidate under Article 4 of the Statute ${ }^{63}$ Even though the national group is not recommended to consult States under Article 6 of the Statute ${ }^{64}$ they remain central throughout the entire process: they nominate the four members of the Permanent Court of Arbitration; they finance and control the campaigning process; and of course, it is States who cast final votes in the General Assembly and the Security Council[ [5] Moreover, whatever the merits of the election procedure, ${ }^{66}$

194, para. 6; and Christine van der Wyngaert was nominated by Belgium in Arrest Warrant of 11 April 2000 (Democratic Republic of the Congo v Belgium), Judgment, ICJ Reports 2002, p. 3, at 6 , para 3 .

60 The sentiment in other international courts with more experience with female judges suggests that gender equality is perceived with some ambivalence. See for example Mackenzie et al, supra note 29, at 48-9.

61 But $c f$. L. Baum, Judges and their Audiences: A Perspective on Judicial Behavior (Princeton University Press, 2006), at 4 who claims that judges are sensitive to the "regard" of salient audiences simply for the sake of that regard.

62 J. Basdevant, 'The Judiciary in the International Sphere', (1949) (No 9) 7 United Nations Bulletin 503.

63 Mackenzie and Sands, supra note 12, at 226.

${ }^{64}$ But see P. Georget et al, 'Article 6', in Zimmermann et al, supra note 26, at 250 suggesting that consultation procedures with universities and learned international law societies seem uneven at best.

65 The election process is carefully studied in Mackenzie et al, supra note 29, at 134, who conclude that ICJ elections are not afforded special consideration for the fact that they are high-level judicial vacancies, and instead seem increasingly "ever more highly politicized", as with the general UN election system.

66 This was deliberate: see United Nations Organization Memorandum on the International Court of Justice, 26 September 1945, F.O. 371/50947/U7369. Yet see P. Sands, 'Global Governance and the International Judiciary: Choosing our Judges', (2003) Current Legal Problems 481, at 488-99 who studied records now in the public domain regarding the 1946, 
there is no formal supervisory mechanism in place to review whether candidates for election meet the criteria provided for in Article $2{ }^{67}$ Thus, nominated candidates will rarely hold views which are wholly irreconcilable with State concerns ${ }^{68}$ Furthermore, it has elsewhere been observed ${ }^{69}$ how the Court's judges' career paths prior to election are relatively homogenous, with candidates primarily drawn from the diplomatic corps ${ }^{70}$ or civil service of States, from academia, and, to a diminishing degree relative to the early days of the Permanent Court, from national judiciaries.$^{71}$ In fact, many nominated candi-

1954 and 1960 elections of Lord McNair, Sir Hersch Lauterpacht and Sir Gerald Fitzmaurice, to recall the British Foreign Office's extensive contact with the national group in matters of nomination and selection. From the outset, the Foreign Office saw its role as "to persuade tactfully [its] national group to accept guidance" from the British Government. See also S. Rosenne, 'The Composition of the Court', in L Gross (ed), The Future of the International Court of Justice, Vol. 2 (Oceana, 1976), 377, at 386-7 recounting similar challenges to the election process in 1972; and E. McWhinney, 'Law, Politics and 'Regionalism' in the Nomination and Election of World Court Judges', (1986) 13 Syracuse Journal of International Law and Commerce 1 , at 4 .

${ }^{67}$ Lauterpacht, 'Amendments', supra note 12, at 103.

${ }^{68}$ R. Mackenzie and P. Sands, 'Judicial Selection for International Courts', in K. Malleson and P.H. Russell (eds), Appointing Judges in an Age of Judicial Power (University of Toronto Press, 2007) 213, at 217. See E. Voeten, 'The Politics of International Judicial Appointments', (2009) 9(2) Chicago Journal of International Law 387, at 391 who suggested that States may wish to do any of the following: to increase the credibility of that State in relation to a certain cause or institution; may be motivated by the "distributive implications" of court judgments; may be influenced by norms of what an appropriate judge should be; and may be using international judicial appointments as a form of patronage. The latter point, whilst controversial, cannot be wholly discounted. See Mackenzie et al, supra note 29, at 2-3 who express concern with the "potentially distorting effects" the political element of judicial selection can have on meritorious and independent candidates. Their empirical study of the ICJ and the ICC attempts to test the validity of criticisms of the process of international judicial appointments more generally.

69 But cf. Aznar Gómez, 'Article 4', in Zimmerman et al, supra note 26, at 216-8, pointing out the "secondary tasks" of many of the individuals later elected to the Court, with jurisconsults often also acting in private practice or representing their State abroad.

70 See Abi-Saab, supra note 31, at 168 who refers to a "legal diplomat" as a person who has studied international law, yet, without being a "jurisconsult, practises it primarily through the fora of multilateral diplomacy."

71 Although many of the Court's judges have taught in universities, many in distinguished capacities, of the present bench, only Judge Keith, Judge Bhandari and Judge Sebuntinde have served as domestic judges in their national States. This is in fact an increase, as during the 2009-2012 triennium, Judge Keith was the only judge who could be so characterised. Conversely, generally more than half (of the present bench, President Tomka, Vice-President Sepúlveda-Amor, and Judges Owada, Abraham, Skotnikov, Xue, and Donoghue) have previously served in their national State's foreign ministry or diplomatic corps. Mackenzie et 
dates spend extended periods serving in or close to their foreign ministries ${ }^{72}$ or, in the case of academics, have often spent long periods being of counsel to governments on questions of international law ${ }^{73}$ At the very least, candidates rely on the support of their national State, which must invest considerable political capital in the campaign process ${ }^{74}$ Accordingly, by the time they are nominated, their career path will already have "sensitized them to be especially mindful of the prerogatives of national sovereignty.'75 This being the case, the selection process therefore guarantees a certain community of sentiment on the bench. ${ }^{76}$ qualitatively different from the putative universalism imposed

al, supra note 29 , at 57-9 suggest that despite contested definitions of judicial independence, States nevertheless feel comfortable putting forward diplomats for high judicial office due to their representational capacity and their negotiating experience.

72 Rosenne, supra note 66, at 391 posits that the high proportion of judges who occupied the position of Legal Adviser to their foreign ministries puts them in delicate positions, given that such the exercise of duties relating to that office invariably requires them to acquaint themselves and form an opinion on most currently known international disputes prior to their election to judicial office.

73 E. McWhinney, Les Nations Unies et la formation du droit (Pedone, 1986), at 124. Although he wrote about the elections to the ILC, the process is identical to that for election to Court. See also Samore, supra note 2, at 204-205 and Manouvel, supra note 12, at 210.

74 E. Jouannet, 'Actualité des questions d'indépendance et d'impartialité des juridictions internationales', in H. Ruiz-Fabri and J.M. Sorel (eds), Indépendance et impartialité des juges internationaux (Pedone, 2010) 271, at 283.

75 T.M. Franck and P Prows, 'The Role of Presumptions in International Tribunals', (2005) 4(2) LPICT 197, at 238-9. This was argued specifically in the South West Africa case, supra note 26. See W. Friedmann, 'The Jurisprudential Implications of the South West Africa case', (1967) 6 Columbia Journal of Transnational Law 1, at 3, who suggested that Judges Spender, Fitzmaurice and Gros were particularly liable to such a view; and C.J.R. Dugard, 'The Nuclear Tests Cases and the South West Africa Cases: Some Realism About the International Judicial Decision, 16(3) VaJ Int'l L. 463 [hereinafter Dugard], at 494, who analysed the wider bench in 1966 to conclude that a majority of the Court's judges had long histories of government service. Of the present bench, all Members have performed one or more of the following functions: represented their government as ambassador or other high representative; acted as counsel for their national State in international adjudication, whether before the International Court or another body; acted as legal officer to their foreign or justice ministry; or led a delegation of their national State at a diplomatic conference.

76 Lauterpacht, Function of Law, supra note 12, at 217 refers to these as "class interests", although he also states that they are rare, by virtue of the "categorical imperative of duty" and the "powerful voice of justice"; and in Lauterpacht, 'Amendments', supra note 12, at 102, and Lauterpacht, 'Revision', supra note 12, at 124-6, he emphasises instead that judges should be experts in international law. Franck and Prows, supra note 75, at 242 claim that ICJ judges, sharing a common and self-imposed perception of the limits of their craft, seek refuge from politically or culturally freighted disagreements by way of "neutered disagreements" about facts, thus leaving an important part of its work-"promoting growth of the law through 
by Article 9 ${ }^{77}$ This view is distinct from the argument that individual judges are beholden to their State in an individual capacity ${ }^{78}$ and it does not require one to impugn the impartiality of members of the Court vis-à-vis their national State (or any other). Even so, it suffices to observe that the judges, as a group, are intellectually disposed to a legal reasoning broadly resembling that of the State with whom they have the closest connection, and that such judges will arrive at similar conclusions to the said States "par affinité, parenté ou identité intellectuelle: ${ }^{79}$ Accordingly, one can identify objectively an intellectual affinity of international judges with the policies of States, a wholly different argument than that of institutional control by States over the work of international courts ${ }^{80}$

Whilst compliance with ICJ judgments is generally considered high. ${ }^{81}$ the continued activity of the Court depends on more than merely satisfying the parties before it (or the requesting international organ); it also must contend with potential and future disputes between States. Thus, the Court must not only demonstrate a modicum of independence and impartiality when deciding cases, but it must also demonstrate a view of substantive international law that

conceptualization and intellectual struggle"-undone.

77 Malleson et al, supra note 14, at 31 in conducting interviews with senior diplomatic staff, serving and retired judges, have called attention to a certain disquiet that the concept of "equitable geographical distribution" embodied in Article 9 is in fact unfair, "petrifying" power balances of the Charter era and strongly favouring Europe (including the geopolitically obsolete "Eastern European Group") to the detriment of Asia and other regions. That concept also applies, of course, in relation to the Security Council: see Article 23 of the UN Charter.

78 Ibid., at 26-7 recounting how an ICJ judge explained feeling like an "ambassador" of his State at times.

79 G. de Lacharrière, La politique juridique extérieure (Masson, 1989), at 157; and as he points out, this is in fact in perfect harmony with the representational condition found in Article 9 of the ICJ Statute, supra note 28.

${ }^{80} \mathrm{Cf}$. the concerns over judicial independence expressed by E. Benvenisti and G.W. Downs, 'Prospects for the Increased Independence of International Courts and Tribunals', (2011) 12(5) German Law Journal 1057; Cogan, supra note 2; A. von Bogdandy \& I. Venzke, 'In Whose Name? An Investigation of International Courts' Public Authority and its Democratic Justification', (2012) 23 (1) EJIL 7; and R. Mackenzie \& P. Sands, 'International Courts and Tribunals and the Independence of the International Judge', (2003) 44 Harv. Int'l L.J 271.

81 C. Paulson, 'Compliance with Final Judgments of the International Court of Justice Since 1987', (2004) 98 AJIL 434, at 436-59, established that, of the fourteen cases filed since 1987, nine have been complied with in full and five have met with "partial compliance". See, generally, C. Schulte, Compliance with the Decisions of the International Court (OUP, 2004). Cf. Posner and Yoo, supra note 5, at 37 who claim that despite a compliance rate of $85.7 \%$ in cases brought to the Court via compromis, the rate falls to $60 \%$ in cases brought via compromissory clause and $40 \%$ in cases brought by way of the Optional Clause mechanism. 
is State-centric, in the sense that it assigns a high value to considerations of State sovereignty and consent when ascertaining rules of international law.

\subsection{Allegations of partiality, or of national/political bias}

As noted above, the most controversial and damaging accusation levelled against judges of the Court is that they are guilty of partiality, or of national or political bias; and numerous academic studies have been devoted to either proving or disproving this very point ${ }^{82}$ Consideration of bias is not easily discernible from the Court's judgments, as it has not made many statements regarding the requirement of impartiality and conscientiousness embodied in Article 20 of its Statute, ${ }^{83}$ and in the various safeguards built into its Rules ${ }^{84}$ However, it may be helpful to consider the experience of other judicial institutions, especially the Rules of the European Court of Human Rights, ${ }^{85}$ and the Code of Judicial Ethics of the International Criminal Court,

82 See supra note 2, for a list of these studies. Mégret, supra note 4, at 48-62 elucidates a list of factors relevant in assessing the partiality of statements or declarations made by judges, or experts required to be impartial. Distilled as much as possible, the criteria are as follows: (i) whether such statements/declarations are sufficiently related to a given case; (ii) whether they are sufficiently specific as to relate strongly to a case; (iii) whether they are sufficiently recent in time so as to have weight in assessing the present partiality of the judge; (iv) whether they are absolute statements, or merely relative (i.e. whether the statement would suggest that the judge remains open to inquiry or counter-proof); (v) whether the statements are of a consensual or of a polemical nature, in that they merely restate widely-held positions, or they arrive at conclusions before investigations have taken place; (vi) whether the statements represent the taking of a legal position or merely a view about what facts actually occurred; (vii) whether statements were made in an official capacity, or merely in a private capacity; (viii) whether the statements are made in an expert (ie as a normative conclusion based on expertise) or activist (ie as a argumentative position taken within a debate) capacity; (ix) whether the statement was made in a private or public setting.

${ }^{83}$ Article 20 ICJ Statute, supra note 28. Guidance is sparse on this point. It is perhaps telling that for D.E. Kahn, 'Article 20' in Zimmermann et al, supra note 26, at 369, there is no selected bibliography.

84 The equality of the parties is a consideration that permeates the Rules in general, with extensive deference to the views of both parties throughout the decision of a case. See especially the rules regarding the submission of written documents (Articles 44-53), the conduct of oral proceedings (Articles 54-72), and those relating to the composition of the Court and the procedures for nominating judges ad hoc (Articles 32-37 of the Rules).

85 Rule 28.2 of the 2012 Rules of the European Court of Human Rights (last amended 1 May 2012) provides that "a judge may not take part in the consideration of any case if ... he or she has expressed opinions publicly, through the communications media, in writing, through his 
both of which place a high emphasis on the appearance of impartiality ${ }^{86}$ One might also wish to consider the ICTY's Furundžija judgment, issued in response to the defendant's attempt to disqualify the presiding trial judge, Florence Mumba, on the basis of her prior membership of the UN Commission on the Status of Women. Mr Furundžija claimed that the trial judgment was used by Judge Mumba to promote the legal and political agenda of that Commission. ${ }^{87}$ Rejecting this submission, the Tribunal elaborated a relatively broad interpretation of the similar requirement of "impartiality and integrity" ${ }^{88}$ contained in its Statute, placing an emphasis on the "appearance of impartiality." ${ }^{89}$ The Special Court for Sierra Leone has also moved towards this broader standard, suggesting that the apprehension of bias by a reasonable bystander was legitimate reason to consider that an objective test of impartiality was not met ${ }^{90}$ Extra-judicially, ICTY President Meron has called attention to the "importance of being sensitive to the possibility of a public perception of bias.'91

A contextual analysis of the Court's case law reveals at least two instances where considerations of impartiality manifested themselves in the opinion of a member of the Court. Politically, the Nicaragua judgment placed the Court on

or her public actions or otherwise, that are objectively capable of adversely affecting his or her impartiality."

${ }^{86}$ Article 4, Code of Judicial Ethics, ICC-BD/02-01-05 (adopted 09.03.2005): "1. Judges shall be impartial and ensure the appearance of impartiality in the discharge of their judicial functions. 2. Judges shall avoid any conflict of interest, or being placed in a situation which might reasonably be perceived as giving rise to a conflict of interest" [Emphasis added].

${ }^{87}$ Prosecutor v Furundžija, Judgment of 21 July 2000, Case No IT-95-17/1A, 2002, at 169-70.

${ }^{88}$ Ibid., at 189: "A) A Judge is not impartial if it is shown that actual bias exists; B) There is an unacceptable appearance of bias if: (i) a Judge is a party to the case, or has a financial or proprietary interest in the outcome of a case, or if the Judge's decision will lead to the promotion of a cause in which he or she is involved, together with one of the parties. Under these circumstances, a Judge's disqualification from the case is automatic; or (ii) the circumstances would lead a reasonable observer, properly informed, to reasonably apprehend bias."

${ }^{89}$ Article 13, Statute of the International Tribunal for the Prosecution of Persons Responsible for Serious Violations of International Humanitarian Law Committed in the Territory of the Former Yugoslavia since 1991, SC Res. 827, UN Docs S/25704/36, annex (1993) and S/25704/Add.1 (1993), UN Doc S/RES/827, 25 May 1993.

${ }^{90}$ Prosecutor $v$ Issa Hassan Sesay, Decision on Defence Motion Seeking the Disqualification of Justice Roberston from the Appeals Chamber, Case No. SCSL-2004-15-AR15, 2004, at 15.

91 Meron, supra note 25, at 362. Although Meron retains faith in international judges acting in a conscientious, scrupulously impartial manner, he argues that the mere appearance of bias can compromise the reputation of the judiciary, and as such, must remain a foremost consideration for judges. 
the defensive after the United States publicly impugned its members for lacking impartiality, failing to consider "irrefutable evidence" and characterising its judgment as a "departure from its tradition of judicial restraint." ${ }^{92}$ In the merits phase, Judge Lachs appeared to rebut American accusations levelled against him 93

A judge-as needs no emphasis-is bound to be impartial, objective, detached, disinterested and unbiased. In invoking the assistance of this Court or accepting its jurisdiction, States must feel assured that the facts of the dispute will be properly elicited; they must have the certainty that their jural relationship will be properly defined and that no partiality will result in injustice towards them. Thus those on the bench may represent different schools of law, may have different ideas about law and justice, be inspired by conflicting philosophies or travel on divergent roads-as indeed will often be true of the States parties to a case-and that their characters, outlook and background will widely differ is virtually a corollary of the diversity imposed by the Statute. But whatever philosophy the judges may confess they are bound to "master the acts" and then apply to them the law with utmost honesty.

[...]

This variety of origin is certainly the great strength of this Court. It is a major contributory factor to the confidence that all states may feel in the balanced nature of the Court's decisions and the broad spectrum of legal opinion they represent. But can this diversity

92 18 January 1985 statement of the US State Department, reprinted in M.N. Leich, 'Contemporary Practice of the United States Relating to International Law', (1985) 79 AJIL 431, at 440-1, reprinted in New York Times, 19 January 1985, at 4, cols 1-6.

93 The State Department was unequivocal, ibid: "We will not risk US national security by presenting ... material ... before a Court that includes two judges from Warsaw Pact nations. This problem only confirms the reality that such issues are not suited for the International Court of Justice." Judge Jennings, albeit not directly targeted himself, nevertheless felt obliged to defend his brethren, in Military and Paramilitary Activities in and against Nicaragua (Nicaragua v United States), Merits, Judgment, ICJ Reports 1986, p. 14, at 528 (Judge Jennings, Dissenting Opinion): "I also wish to express my regret that, in a Court which by its Statute is elected in such a way as to assure 'the representation of the main forms of civilisation and of the principal legal systems of the world', the United States in its statement accompanying the announcement of the non-participation in the present phase of the case should have chosen not refer to the national origins of two of the Judges who took part in the earlier phases of the case." 
justify an invidious distinction between Judges according to their nationality or the alliances of which their countries may happen to be members? All Judges "should not be only impartial but also independent of control by their own countries or the United Nations Organization". In fact, while they may have served their countries in various capacities, they have had to cut the ties on becoming a Judge 94

Interestingly, he also cited a former American member of the Court, Judge Jessup, who had summarily dismissed the notion that the Court's judges defended their national states, and noted that to prove some kind of national alignment "is often not supportable and may be quite misleading." 95 Judge Lachs even took great pains to comment on and make extensive reference to American jurists (notably Judges Cardozo, Frankfurter and Holmes), almost certainly to rebut the accusation of specifically anti-American bias ${ }^{96}$

The second example is Judge Elaraby in the Israeli Wall Order of $2004{ }^{97} \mathrm{He}$ quoted Judge Lachs' "wise maxim" approvingly at the start of his opinion, which was perhaps unnecessary in that he had voted with the majority on the entire dispositif. However, further study of the historical context behind that Order reveals that Judge Elaraby had been subject to a complaint by Israel regarding his impartiality ${ }^{98}$ on the basis of his role as a legal adviser to the Egyptian Ministry of Foreign Affairs and Legal Adviser to the Egyptian Delegation at Camp David in 1978, as well as an interview given by him in 2001. Although Israel's

${ }^{94}$ Nicaragua (Merits), ibid., p. 158, at 158-9 (Judge Lachs, Separate Opinion). For further discussion of the 'individualisation' of the international judge, see for example Anglo-Iranian Oil Co. Case (United Kingdom v Iran), Judgment, ICJ Reports 1952, p. 93, at 161 (Judge Carneiro, Dissenting Opinion) who noted that "it is inevitable that everyone of us in this Court should retain some trace of his legal education and his former legal activities in his country of origin"; and Legality of the Threat or Use of Nuclear Weapons, Advisory Opinion, ICJ Reports 1996, p. 226, at 275 [hereinafter 'Nuclear Weapons'] (Judge Herczegh, Declaration).

95 Ibid., at 159.

96 Gordon, supra note 38, at 405. It should be noted that Judge Lachs voted in favour of the United States in United States Diplomatic and Consular Staff in Tehran (United States $v$ Iran), Provisional Measures ICJ Reports 1979, p. 7, at 44-5; and Delimitation of the Maritime Boundary in the Gulf of Maine Area (Canada v United States), Order ICJ Reports 1982, p. 3, at 8.

97 Legal Consequences of the Construction of a Wall in the Occupied Palestinian Territory, Advisory Opinion ICJ Reports 2004, p. 136, at 246 [hereinafter 'Israeli Wall'] (Judge Elaraby, Separate Opinion).

98 Ibid., Order of 30 April 2004 on the Composition of the Court ICJ Reports 2004, p. 3, at 4, para. 2. The exact complaint of Israel was that Judge Elaraby "had previously played an active, official and public role as an advocate for a cause that is in contention in [that] case". 
request was dismissed by thirteen votes to one ${ }^{99}$ Judge Buergenthal, the lone dissentient, openly questioned Judge Elaraby's impartiality in his dissenting opinion appended to the Order ${ }^{100}$ Given a situation where even one of his own colleagues doubted his capacity to act impartially, one cannot but infer that Judge Elaraby's separate opinion was motivated by the controversy surrounding him 101

Extra-judicially, Judge Schwebel has proffered the following explanation about the (lack of) impartiality demonstrated by international judges which, in the light of criticism of some of his votes in Nicaragua, takes a discernibly defensive tone:

"We [judges] are all prisoners of our own experience. Such measure of objectivity as may be humanly possible may come more easily to some than others, depending in part on that experience, in which the legal and political culture that conditioned it is important. Clearly judges manifest and in the history of civilisation have manifested a measure of objectivity. If not, the judiciary would not exist.' 102

These rare individual excursions are illustrative of why explicit discussion of this topic by the Court is so exceptional. Even so, the statements reviewed

99 Ibid., para. 9.

${ }^{100}$ Ibid., (Judge Buergenthal, Dissenting Opinion), p. 9, para. 11: "[a] court of law must be free and, in my opinion, is required to consider whether one of its judges has expressed views or taken positions that create the impression that he will not be able to consider the issues raised in a case or advisory opinion in a fair and impartial manner, that is, that he may be deemed to have prejudged one or more of the issues bearing on the subject-matter of the dispute before the court. That is what is meant by the dictum that the fair and proper administration of justice requires that justice not only be done, but that it also be seen to be done".

101 Another instance was arguably Judge Nagendra Singh in Nuclear Tests (Australia v France; New Zealand v France), Judgment ICJ Reports 1974, p. 253, at 457. Dugard, supra note 75, p. 498 contrasted Singh's vote with the majority in December 1974 with his extensive extra-judicial writings condemning the use of nuclear weapons in war and their testing as illegal, cautiously intimating that the fact that India detonated its first nuclear weapon in May 1974 may have influenced his vote.

102 Schwebel, supra note 2, at 895 . Perhaps Judge Schwebel was also responding to murmurs that he was guilty of bias, as it should be noted that Judge Schwebel voted as the sole dissentient in a case involving his national state four times in the Nicaragua case, supra note 93. See Order on Provisional Measures of 10 May 1984, ICJ Reports 1984, p. 169; Order fixing Time-Limits of 4 October 1984, ICJ Reports 1984, p. 209; Declaration of Intervention, ICJ Reports 1984, p. 215, and Nicaragua, supra note 93, Jurisdiction, ICJ Reports 1984, p. 392, and once in Elettronica Sicula S.p.A. (ELSI) (United States v Italy), ICJ Reports 1989, p. 15. 
above demonstrate that concerns about impartiality colour judicial reasoning and condition perceptions of the judicial role. Thus, the structural safeguards built into the Court's Statute ${ }^{103}$ and the Court's collective drafting procedurenamely, avoidance of the juge rapporteur $n^{104}$ and the collective drafting process, the composition of the Court ${ }^{105}$ and its election procedures ${ }^{106}$-seem justified. Finally, and more concretely, concerns about impartiality are the clear impetus behind the practice of "conscientious self-disqualification", when conflict of interest or undue involvement in other aspects of the dispute may exist ${ }^{107}$

${ }^{103}$ Articles 16 and 17 of the ICJ Statute, supra note 28, prohibit judges from assuming certain functions in view of possible conflicts; Article 23 establishes both the right to vacations and the requirement that judges remain at the disposal of the Court; and Article 32(5) provides that their salaries may not be decreased whilst they are in office. These constitute safeguards for the judges against possible institutional interference over selection and tenure, legal discretion, and control over material and human resources. See R.O. Keohane et al., 'Legalized Dispute Resolution: Interstate and Transnational' (2000) 54 International Organization 457, at 460.

${ }^{104}$ Sturé Petrén has extra-judicially listed several factors that made employing a juge rapporteur unworkable for the Court, going so far as to hint at national bias on the part of the member of the Court called upon to fulfil that function. See S. Petrén, 'Forms of Expression of Judicial Activity' in L. Gross (ed.), The Future of the International Court of Justice Vol. 2 (Oceana, 1976), at 448 .

${ }^{105}$ See Article 9 ICJ Statute, supra note 28, which exhorts the electors to bear in mind the "body as a whole"; but cf. L Oppenheim, The Future of International Law (Clarendon Press, 1921), at 43 , arguing that the composition of the Court should not be guided by conceptions of sovereign equality. An excellent early analysis of the composition of the Court and the politics of representation remains that of Rosenne, 'Composition', supra note 66, at 377 . He exhorts moving beyond traditional dichotomies between civil law and common law in favour of a "judicious balance" between all legal cultures, rather than any quantitative analysis.

${ }^{106}$ Meron, supra note 25, at 362 has called outright for the abolition of electioneering by judges, and suggested that international courts not allow for the re-election of judges for that same reason: campaigning is "incompatible with the dignity of the judicial function". See also the suggestion by J. Dugard, 'Article 16', in Zimmermann et al, supra note 26, 303, at 313 that longer terms of office, with no possibility of re-election, might further depoliticise the process; and ABILA Committee for the Settlement of Intergovernmental Disputes, 'Reforming the United Nations: What About the International Court of Justice?', (2006) 5(1) Chinese Journal of International Law 39, at 50, calling for judges to be elected for a single twelve-year term; Lauterpacht, 'Revision', supra note 12, at 122, proposing a single fifteen-year term.

${ }^{107}$ Very little can be abstracted from these practices because the Court is usually content with a brief statement in its Yearbook, providing little public explanation. One can note, however, the factual instances of recusals and study the external facts which might explain these recusals. See for example Barcelona Traction, Light, and Power Company, Limited (Belgium $v$ Spain), Second Phase ICJ Reports 1970, p. 3, where an unnamed judge recused himself. In Frontier Dispute (Burkina Faso/Mali), Judgment ICJ Reports 1986, p. 554, there was a 


\section{Final Reflections on Impartiality}

The notion of judicial impartiality being wedded to concerns over nationality and bias ignores the indirect stake that many states and international actors have in the judicial pronouncements of the Court. With its increased docket, genuine concerns over the structural and institutional constraints described above are ever more salient, and the Court's understanding of its judicial function should be approached from all possible angles.

The Court might indeed-to paraphrase Allott-speak to states the words states want to hear ${ }^{108}$ Yet even if this is so, that phenomenon ought best to be understood in the context in which the Court operates, instead of simply indicting the Court as a biased, subordinate institution. It is true that cannot always come to a case dispassionately and with only knowledge of the case that is put before a court. Experienced judges often come to a case with substantial knowledge of the context or facts surrounding it, and may be chosen precisely because of this relative legal and political 'worldliness $\sqrt{109}$ Yet the fact that judges have convictions and make value judgements, in good faith, in the exercise of their function is not necessarily problematic $]^{110}$ the very ability to abstract

problem in that one of the judges in the Chamber had previously presided over a conciliation commission which attempted to resolve that dispute. Judge Jessup recused himself from the Temple of Preah Vihear (Cambodia v Thailand), Judgment ICJ Reports 1962, p. 6, in which he had previously been connected as counsel, as did Sir Hersch Lauterpacht in Nottebohm (Liechtenstein $v$ Guatemala), Second Phase ICJ Reports 1955, p. 4; the qualités of the judgment did not mention this fact. When Judge Higgins recused herself in Questions of Interpretation and Application of the 1971 Montreal Convention Arising from the Aerial Incident at Lockerbie (Libyan Arab Jamahiriya v United Kingdom), Judgment ICJ Reports 1998, p. 9, at p. 13, para. 9, she was not mentioned by name. Judge Abraham in Certain Questions of Mutual Assistance in Criminal Matters (Djibouti v France), Judgment ICJ Reports 2008, p. 177, at 181-2, para. 6, was referred to as "the Member of the Court of French nationality." Recusal has also been involuntary: in South West Africa (Ethiopia v South Africa; Liberia v South Africa), Second Phase ICJ Reports 1966, p. 6, President Spender summarily announced at the start of oral proceedings that Judge Zafrullah Khan had been recused. For a history of this incident, see W.M. Reisman, 'Revision of the South West Africa Cases' (1966), 7 Virginia Journal of International Law 3, at 55 and Rosenne, 'Composition', supra note 66, at 389-90. See R.Y. Jennings, 'Article 24', in Zimmermann et al, supra note 26, at 420-1, footnote 19, for further examples.

${ }^{108}$ P. Allott, The Health of Nations (CUP, 2002), at 296.

${ }^{109}$ Meron, supra note 25, at 365: "judges are not empty vessels that the litigants fill with content." See also, generally, J. Frank, 'Are Judges Human? Part One: The Effect on Legal Thinking of the Assumption That Judges Behave like Human Beings', (1931) 80 University of Pennsylvania Law Review 17, at 25-9 on the personal element in judicial decision.

${ }^{110}$ Dworkin, supra note 11, at 8-9; Thomas, supra note 15, at 242. 
oneself from one's individual predilections and to consider all viewpoints with a fair, open mind could even feed on one having a 'relatively vigorous subjectivity' in the first instance ${ }^{111}$ In short, the very notion of impartiality is relatively indeterminate.

I suggest instead that the notion of impartiality should be understood "against a background of partiality" 112 as an understanding by judges that they do carry with them prior experiences and predispositions that they must rationalise when making decisions based on law. Far from a praetorian guard of states' interests, the Court's judges define themselves through their fidelity to the rules of international law itself $\left[{ }^{113}\right.$ The Court's judges perceive the essence of their role to remain faithful-or partial-to the rules, standards and values that constitute the legal system ${ }^{114}$ As such, the concept of judicial impartiality would better be conceptualised by "visualising, ${ }^{115}$ the judges within the context of the rules that they apply, rather than to be impartial in respect of the rules that they apply ${ }^{116}$ Rather than to extinguish them fully, judges should strive to remain aware of pre-judgements and values ${ }^{117}$ and retain a "reflective critical attitude" to the standards (or rules) they follow, apply and interpret ${ }^{118}$ For in the final analysis, what is asked of judges is good judgement, and not simply a resolution of the dispute: the judicial role requires constant, discerning assessment of what the law, and its underpinning purposes, require in a particular case.

\footnotetext{
111 Mégret, supra note 4, at 44.

${ }^{112}$ Lucy, supra note 19, at 15.

${ }^{113}$ Meron, supra note 25, at 369 expressly invokes the term "fidelity."
}

${ }^{114}$ D. Kennedy, 'Freedom and Constraint in Adjudication: A Critical Phenomenology', (1986) 36 Journal of Legal Education 518, at 522 characterises the interplay between values and these 'pseudo-objective' rules as perhaps one of the major constraining factors on judicial work.

115 J. Dickinson, 'Legal Rules: Their Function in the Process of Decision', (1931) 79 University of Pennsylvania Law Review 833, at 844 who suggests that one know the "rule of decision"; that is, not only the substantive rules in issue, but rather, how judges perceive and implement the rules, which turns on the judges' views on the function of the law, as well as their own function.

${ }^{116}$ Lucy, supra note 19, at 25.

117 As concludes Minow, supra note 20, at 1217: "[w]e want judges ... to be objective about the facts and the questions of guilt and innocence but committed to building upon what they already know about the world, human beings, and each person's own implication in the lives of others. Pretending not to know risks leaving unexamined the very assumptions that deserve reconsideration."

118 Hart, supra note 21, at 57. 